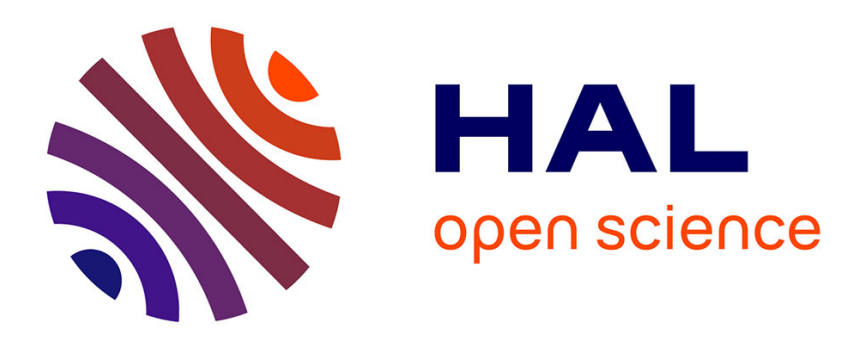

\title{
The Role of Policy Transfer in Assessing the Impact of American Ideas on British Social Policy
}

Rob Hulme

\section{To cite this version:}

Rob Hulme. The Role of Policy Transfer in Assessing the Impact of American Ideas on British Social Policy. Global Social Policy, 2006, 6 (2), pp.173-195. 10.1177/1468018106065365 . hal-00571793

\section{HAL Id: hal-00571793 \\ https://hal.science/hal-00571793}

Submitted on 1 Mar 2011

HAL is a multi-disciplinary open access archive for the deposit and dissemination of scientific research documents, whether they are published or not. The documents may come from teaching and research institutions in France or abroad, or from public or private research centers.
L'archive ouverte pluridisciplinaire HAL, est destinée au dépôt et à la diffusion de documents scientifiques de niveau recherche, publiés ou non, émanant des établissements d'enseignement et de recherche français ou étrangers, des laboratoires publics ou privés. 


\title{
The Role of Policy Transfer in Assessing the Impact of American Ideas on British Social Policy
}

\author{
ROB HULME \\ University of Chester, $U K$
}

\begin{abstract}
AB STRACT This article assesses the contribution of existing work on policy transfer to our understanding of policy change on the international stage. It explores the impact of American ideas and practices on aspects of social policy in the UK. It argues for a focus on the role of 'epistemic communities' and policy learning in the development of generic international agendas such as the 'Americanized medical model' of evidence-based practice adopted by the New Labour government in health and education. It argues that international social policy analysis should take account of the movement of ideas and practices at three levels: global/international, national and inter-organizational.
\end{abstract}

K EYWORDS epistemic communities, evidence-based practice, learning, New Labour, policy transfer

There is nothing very 'new' about New Labour's social policies, including its education policy. Genuine innovation in education policy development has been almost completely absent since 1997 in a process involving the recycling, redefinition and reconstitution of policy ideas and instruments from previous Conservative governments, from other countries, principally the USA, and from other areas of British social policy, particularly welfare and health.

The influence of American ideas and practices on British social policy development pre-dates New Labour's 'Anglicised communitarianism'. Previous Conservative governments in the UK were strongly influenced by American 
academics and think tanks and their approach to social policy, ranging from welfare to university reform, owed a great deal to American conservatism. The eastward movement of ideas is well established and well documented but what is the nature of US influence on social policy in the UK? What do British decision makers look for in American policy development and how successful are they in importing policy ideas and instruments? What does the trans-Atlantic search for policy knowledge mean for the development of perspectives on global social policy? To what extent does the import of generic policy ideas, featuring so prominently in the development of the evidencebased movement in education, represent an act of 'indirect transfer' of methodologies and policies from the health sector? These issues are explored in this article though an assessment of the impact of the transfer of ideas from the US and domestic sources in the development of education policy in the UK, primarily the development of the evidence-based movement in education. It is argued that the model of evidence-based practice (EBP) for education is an 'Americanized medical model'.

The article begins by assessing the contribution made by established work on policy transfer to our understanding of how and why policy changes in a complex arena such as education policy. The existing frameworks of policy transfer are presented as analytical tools which help to provide a valuable interdisciplinary dialogue on the role of ideology and the motivations of all actors in the policy process. The article explores the role of 'epistemic communities' in the development of generic global agendas such as evidencebased practice. It is argued that in analysing the process of international policy learning involving the transfer of ideas, we can advance our understanding of the operation of global social policy.

The article moves on to examine the ways in which New Labour has transferred ideas and policies about evidence-based practice from the health sector. ${ }^{1}$ Many of these ideas had their origins in Canadian and American medical research centres. Since the late 1990s the British Government has encouraged the development of an evidence-based movement in education. The impact of this upon policy has been seen most starkly in the creation of initiatives designed to establish 'best practice' and 'what works' in education. Two significant policy initiatives within this trajectory were the creation of Best Practice Research Scholarships for teachers and the Networked Learning Communities Programme established by the National College for School Leadership. Earlier work on the impact of US ideas on the reform of British post-compulsory education under the Conservatives and the impact of US practice in tackling social exclusion in education are also referenced.

The third section of the article explores the multi-level nature of transfer and policy learning in these cases. Evidence-based practice must be seen first, as the foremost item in a rapidly emerging global agenda for managerialist education reform. At the level of domestic structures, the case of EBP offers 
a case study in cross-sectoral transfer, which is interesting in its contrasts with other areas of education policy. The major problems arising from the transfer here relate to the specificity of policy based on an approach to research, which was intended for medical practitioners. Such policy does not and perhaps should not be applied to education. EBP offers an interesting case study in inter-organizational transfer. The role of UK education academics acting as 'epistemics' and advocates of the Americanized medical model of best practice for education is particularly interesting. Some of the leading 'epistemics' have been instrumental in establishing the research centres that are leading the evidence-based movement.

The article concludes by drawing together some of the most significant patterns and consequences of the use of American ideas in British education policy development. The most consistent pattern can be generalized from the approach that New Labour has adopted to EBP. British governments have attempted to 'learn' for the long term or 'borrow' for the short term as a 'rationalistic' response to changing global circumstances, but also as a means of acquiring tried and tested policy responses that will bring about their political goals. One of the most consistent messages in the policy transfer literature is that partial transfer leads to policy failure. Yet, in our primary example, New Labour has, through very selective use of policy-oriented learning and research, found in EBP a convenient instrument to control teachers while using inclusive language in the construction of education agendas.

\section{What is Policy Transfer?}

\section{DEFINITIONS AND FRAMEWORKS}

In the simplest of senses, there is nothing new about policy transfer. Through work such as Dolowitz et al. (2000), Dolowitz and Marsh (1996), Evans and Davies (1999), frameworks have been developed which seek to advance earlier debates about the international movement of ideas and practices in social policy through concepts such as diffusion and lesson drawing (Rose, 1991). These studies offer us frameworks rather than models or complete theoretical perspectives and accordingly, the literature is built upon the straightforward proposition that policy transfer represents:

A process in which knowledge about policies, institutions and ideas developed in one time or place is used in the development of policies, institutions etc. in another time or place. (Dolowitz et al., 2000: 3)

The following analytical framework offered in Dolowitz et al. (2000) both describes the process of policy transfer and provides a framework for exploring the international movement of policy. It is based on nine questions: 
1. Why and when do actors engage in policy transfer?

2. Who transfers policy?

3. What is transferred?

4. From where are lessons drawn?

5. Are there different degrees of transfer?

6. When do actors engage in policy transfer and how does this affect the policy making and policy transfer processes?

7. What restricts policy transfer?

8. How can researchers begin demonstrating the occurrence of policy transfer?

9. How can policy transfer help our understanding of policy failure? (Dolowitz et al., 2000: 9)

The literature offers a multi-level framework of policy analysis for exploring the movement of policy ideas and practices at three levels. These levels are fluid and their boundaries can be blurred. The rise of generic agendas and policy platforms such as the evidence-based movement in health and education is global in its reach, international in that an American-informed notion of EBP has formed a part of Anglo-American policy transfer, and interorganizational in that it has developed from links between individual policy entrepreneurs and epistemics. The framework, however, provides us with a useful heuristic devise. At the level of global, international/trans-national structures, transfer studies offer a focus on the increasing complexity of the 'global policy community' and the rise of generic agendas in education and other welfare policies. At the level of domestic governance, policy ideas and practices are transferred 'indirectly' across sectors and from previous governments or policy trajectories (New Labour's education reforms ranging from Higher Education Reform to the involvement of the private sector in school organization have significant antecedents in previous Conservative government policy). Policy transfer meanwhile operates at the inter-organizational level. Here, the movement of ideas and practices can be domestic or international, top-down or bottom-up and can bypass the central institutions of domestic governance. Depending on the context of the transferring agents, policy transfer can be either voluntary or coercive (obligated transfer), direct or indirect. At all levels, the literature suggests that the transfer of ideas and institutions is a key instrument in policy development.

POLICY TRANSFER AS ANALYTICAL TOOL:

CONNECTING LITERATURES IN POLICY MAKING

I argue that the most significant contribution of existing work on policy transfer is that it provides an opportunity to illuminate the processes of policy change. The power of the framework to singly 'explain' anything is limited, but its capacity to enhance the explanatory power of other perspectives on international and domestic policy making is considerable. It offers us an analytical tool to connect accounts of policy change based on processes with more 
critical perspectives of policy based on ideology and discourse. This is achieved primarily through the focus the transfer literature provides on policy learning. The policy transfer frameworks compel us to examine the origins of 'new' knowledge about policy, who supplies such knowledge and the political and practical purposes to which this knowledge is put. Consequently, we can understand more about the nature of policy development at any level and at any stage in the policy process.

In a field of social policy as complex as education an account of policy change requires broad perspectives on structural change and ideology and a narrower focus on processes. It is a field in which academic perspectives have 'talked past one another' in accounting for how and why policy changes.

Critical policy sociologists such as Ball $(1990,1998)$ and Olssen et al. (2004) have given us Foucauldian-influenced accounts of policy change in education. Ball in particular has argued convincingly that policy making in education is evolutionary and fluid rather than rational-technocratic and linear with orderly stages and decision points. The struggle between policy actors and the discourses they generate is carried out throughout the levels of the educational state. As a consequence, policy changes meaning in moving from 'the context of influence', as Ball terms it, where think tanks, civil servants and policy advisers nationally and internationally compete to mould and shape policy, to the 'context of practice', where regional, local and institutional actors can reinterpret policy at the 'chalk face'. Policy sociology is valuable in providing theoretical depth to accounts of policy change and in highlighting the proclivity of educational policy makers to idealize and transfer notions of educational practice from the past.

Within the traditional literature on policy making there is a total absence of an account of how policy changes. One of the greatest utilities of the transfer framework is to shed light on the strategic motivations of actors in the policy process, whether these are financial, ideological or simply pragmatic. The case studies offered in Dolowitz et al. (2000), such as the Americanization of British higher education, reveal that transferring policy is rational, since it is about making choices in policy development, but it is also about realizing ideological goals. Whether change is required because of major systemic disruptions or crises, or whether an adaptation of an already established policy is necessary, policy makers must respond intelligently by making use of knowledge transferred from other contexts. One of the more under-developed uses of the transfer framework for policy making theory is its capacity to provide a focus on strategic change but also to highlight the reasons for policy continuity and short-term pragmatism.

During the 1990s policy theory took a more critical turn in order to address the absence of the 'politics of policy making' and the internationalization of policy processes. This 'deepening' of policy theory has involved two general movements, both of which have important implications for the use of policy transfer as an analytical tool. The first of these featured a rejection of formulaic 
policy processes, promoting instead a notion of policy making based on the interaction of groups of actors aligned by interest and mutual resource dependence in the case of policy networks (Marsh and Rhodes, 1993), or ideology in the form of advocacy or discourse coalitions (Fischer and Forrester, 1993; King, 1999; Sabatier and Jenkins-Smith, 1993). Second, this critical turn was advanced through work on policy-oriented learning and the role of knowledge in the policy process (Haas, 1990, 1992; Rose, 1991). Haas in particular establishes a connection between policy change and learning on the part of policy makers, who cannot achieve the delivery of policy reflecting their ideology without new knowledge on how to put this into effect. This literature is significant in highlighting the role of 'epistemic communities' or competing groups of policy specialists, often found in think tanks (Stone, 2000, 2001). The policy transfer literature offers a useful development on this work because the supply of knowledge by 'epistemics' involves the transfer of ideas from other contexts - either other countries or the domestic past.

\section{THE ROLE OF POLICY TRANSFER IN POLICY MAKING:}

POLICY LEARNING

Policy-oriented learning is also a multi-level concept since it can take place between Ministers and civil servants, think tanks and 'invisible colleges' of policy advisors or between groups of academic experts or practitioners in different counties linked only by email. The nature of learning is fluid and complex. The level at which it takes place, the origin of the ideas underpinning it and the uses to which it is put vary in each individual case. For Haas (1990), however, policy change cannot take place without learning. He produces a knowledge-based definition of policies as packages of cause-effect prescriptions founded on 'scientific knowledge'. Such knowledge is (at the level of central government institutions) based primarily on quantitative data supplied by professional organizations or policy specialists. Scientific knowledge is then moulded into 'consensual knowledge', or commonly accepted cause and effect propositions (i.e. in education policy, standards in education reflect the performance of teachers), which define the nature of policy problems and shape the responses available to government. Any departure from an existing policy requires learning on the part of policy makers or, 'the penetration of political objectives and programmes by new knowledge' (Haas, 1990: 316). Thus, learning is primarily about the use of knowledge to define political interests and to refine the strategic direction of policy proposals.

Epistemic communities provide such knowledge, which acts as a 'trigger for learning' in helping to break policy makers' habits and their tendency to look for continuity and stability in policy. Haas (1990: 41) defines them as groups of professionals 'usually recruited from several disciplines', linked by specialist knowledge and acting as a conduit for that knowledge in the service of policy makers. They may 'share a common causal model and set of beliefs' but unlike Sabatier and Jenkins-Smith's (1993) advocacy coalitions, this is more 
akin to a community of scientists 'like biologists' than to groups bound together by ideological principles. Rose (1991) offers a view of epistemic communities as 'invisible colleges' of experts; he refers to an epistemic community of education specialists comprising local authorities, national civil servants, regional actors, professional associations and think tanks. He observes that, 'their locus and level may change but the focus remains education policy' (Rose, 1991: 16). If there is more than one epistemic community in a policy environment they can be seen to behave like 'rival groups of scientists' (Haas, 1990: 42) in that the ultimate test of their 'version of the truth' is the adoption of their prognoses by the users of knowledge.

The policy transfer framework provides an essential linkage that allows the diverse literatures referred to above to converse. Drawing on the central tenets of all of this work we can explain policy change in education as the product of the interaction or confluence of three interdependent determinants: policyoriented learning on the part of significant actors in the educational state, which in turn leads to refinement of the ideological basis of policy platforms, and changes to the systemic determinants of policy, such as movements in the global economy. Policy transfer then, is a rational and an ideological strategy to deal with changing circumstance. Seeking workable, tried and tested, readily available definitions and responses from other countries, and from the past, is the means by which policy makers put their learning into effect.

The primary focus of the literature to date has been upon the first two levels of transfer - trans/international exchanges of ideas fuelled by international networks and transfer at the level of domestic structures or within the national policy-making machinery. In education, however, there are burgeoning examples of transfer at the inter-organizational level, often bypassing the other levels. I have argued elsewhere (Dolowitz et al., 2000) that knowledgebased actors have been instrumental in the exchange of ideas leading to the 'Americanization' in form and content of British higher education since the late 1980s. Here, actors within the central domestic policy networks of both governments drive the process of change and indeed seek to control the policy agenda through the transfer of pre-existing policy. This is often the case in education policy but central actors are not always so successful in their quest to retain control of their environment. There is a bottom-up aspect to policy learning in education, which involves transfer in the context of practice. Over the past decade, this has developed a particularly European focus through networks such as Tempus and Erasmus as well as transatlantic via the contact between US and UK universities and other participants in US-UK learning communities (Hulme and Hulme, 2000a, b). This process has been given greater impetus by the UK's participation in the Bologna process. Indeed, this highlights a characteristic feature of education policy in that effective 'policy learning' and use of transferred knowledge is that which comes from the 'bottom-up', from organizations seeking good practice from one another as international learning communities develop, academics 
seeking to diffuse their research and on occasion organizations acting as policy entrepreneurs or pioneers (e.g. TEMPUS and other EU initiatives in eastern Europe and Russia, partnerships between British and US universities/ local education authorities). It is in the context of educational practice that learning is most effectively and positively 'transferable'. Transfer and learning within the making of education policy in the 'contexts of influence' and professional practice at this level requires more work in order to deepen the framework and add greater reflexivity to its theoretical utility.

\section{Anglo-American Policy Transfer in Education Policy}

I have written elsewhere of the impact of policy transfer from the USA on British policy development in education (Dolowitz et al., 2000; Hulme and Hulme 2000a, b). The remainder of this article makes very brief reference to this work in order to augment the primary example offered of evidence-based practice in education and to highlight the differing impact of US ideas and policies in each case. The third section applies the multi-level transfer model and the article concludes by making some overall conclusions on the impact of US ideas on British education policy over the past two decades.

\section{WHY THE USA?}

The trans-Atlantic traffic of ideas policies and practices from the USA to the UK in education and other aspects of social policy and welfare over the past 20 years are well documented at the level of international and national institutional structures (Ball, 1998; Daguerre and Taylor-Gooby, 2004; Dolowitz and Marsh, 1996; Dolowitz et al., 2000). This work outlines a very well-established pattern of 'Americanized' British policy development. The eastward drift of ideas at the level of central executives is sustained by three factors. First, it is sustained by the close links between epistemic communities and networks of knowledge-based actors in and around the central executives of both countries. Second, these relationships are fuelled by common cultural values and ideological links between political projects. The 'atmospheric' influence of academics in constructing the key ideological discourses of Anglo-American learning over the past 20 years, such as Hayek, Selznick and Etzioni, and concurrently, the brokerage of the text and discourse underpinning policy orchestrated by think tanks such as the Institute for Economic Affairs and the Social Market Foundation, cannot be understated.

In recent times, this began in the Reagan-Thatcher era and evolved through the Clinton-Blair relationships of the late 1990s into a trajectory of social policy that Alan Deacon (2000) has termed 'Anglicised communitarianism'. Currently, this process has been sustained in terms of international policy developed by Bush and Blair. The third factor relates to policy complexity. The rates of policy failure in a complex arena such as education are 
very high and the British Government has looked for ready-made solutions to long-term problems and the USA offers a multi-state market for solutions. As Daguerre and Taylor-Gooby (2004) observe, the process of USA-UK transfer is facilitated by the highly centralized nature of British policy making in all areas of British social policy and the absence of veto points within the central executive. A fourth and less well-documented factor arises from a combination of the other three. At the inter-organizational level there is evidence (Hulme and Hulme, 2000a, b) that trans-Atlantic communities of learning comprising variously academics, officials from local education authorities or educational managers, sustain the process of learning about policy at practice though shared practice and exemplar.

\section{POLICY TRANSFER AND EVIDENCE-BASED PRACTICE IN \\ EDUCATION}

The current zeitgeist of evidence-based policy and practice in health and education has its roots in the marketization of public services in the 1980s. Its rhetoric about responsiveness to 'relevant', practice-oriented research grew from the managerialist reforms of the Conservatives with its attendant emphasis on 'outcomes' as indicators of efficiency and effectiveness. It is therefore, a prime example of reconstituted policy, partially transferred from the past and selectively blended with elements of practice from the USA and from another sector.

In a manner which has parallels with the previous Conservative political project, New Labour's ideological position carries with it unresolved tensions. The internal friction between market and social justice principles is clearly discernible in education policy. Although Jones (1996: 18) rightly claims that, New Labour's politics are too much of a bricolage for us to trace them to any one philosophical source', it is possible to identify two dominant ideological discourses underpinning New Labour's education policy agenda. These can be labelled 'social progressivism' and 'economic progressivism'. The former involves the pursuit of social democratic ideals via an 'actively strong state'. The latter reiterates the economic function of education as essential to economic prosperity. However, unlike the economic rationalism of the New Right, 'economic progressivism' has 'no real ideological construction and appears to be the result of an informed acceptance of the market at work', i.e. the market concept becomes reified as an adjunct of globalization/modernization processes. This has provided the political space for New Labour to absorb conservative managerialist positions and adapt ideas taken from other contexts in pursuing its cross-sectoral commitment to evidence-based practice in the UK public sector.

The evidence-based movement that has developed in the UK involves a rejection of older forms of decision making based on anecdotal professional experience and a view of medicine and in turn education as a lifelong, problemsolving process involving responsiveness to practice-related research. 
Evidence-based practice (EBP) is an approach to health care wherein health professionals use the best evidence possible i.e. the most appropriate information available, to make clinical decisions for individual patients. EBP values, enhances and builds on clinical expertise, knowledge of disease mechanisms, and pathophysiology. It involves complex and conscientious decision-making, based not only on the available evidence but also on patient characteristics, situations and preferences. It recognises that healthcare is individualised and ever changing and involves uncertainties and probabilities. Ultimately EBP is the formalisation of the care process that the best clinicians have practised for generations. (McKibbon, 1998: 399)

The most visible instrument of the government's approach has been the Centre for Management and Policy Studies (CMPS) within the Cabinet Office, which was established as a source of 'evidence of best practice' for policy makers across the public services. The guiding principle underpinning policy has been the notion of 'best practice' and this is drawn from the systemic review of research in the social and political sciences (Davies et al., 2000; Thomas and Pring, 2004). The terminology and methodology adopted has been transferred directly from policy made in the health sector over the past 15 years. The Department for Education and Employment/Department for Education and Skills (DfEE/DfES) education research budget grew from $£ 5.4 \mathrm{~m}$ in 1997 to $£ 10.4 \mathrm{~m}$ for $2001 / 2$ at the peak of policy formulation. Funding has been increasingly channelled towards 'what works' or 'best practice', i.e. the effectiveness of interventions in social policy (Evans et al., 2000).

Social science should be at the heart of policy-making. We need a revolution in relations between government and the social research community - we need social scientists to help to determine what works and why, and what types of policy initiatives are likely to be most effective. (Blunkett, 2000)

The problem for New Labour's education policy makers is that British education research, in terms of research culture in universities and the primarily qualitative outputs of education academics, did not fit the North American inspired medical model on which its formulation was based. Accordingly, new dedicated research centres were encouraged. This initiative culminated in the Centre for Evidence-Informed Policy and Practice (EPPI) directed by Professor Ann Oakley based at the Institute of Education, the Wider Benefits of Learning Research Centre directed by Professor John Bynner, based at the Institute of Education, Birkbeck College, and the Centre on the Economics of Education.

The evidence-based movement has been pioneered by a number of academics acting as policy entrepreneurs and advocates of change. David Hargreaves (1996) was influential on policy directed at research funding; in a series of highly publicized attacks he spoke of education research as, 'a private, esoteric activity, seen as irrelevant by most practitioners'. Concurrently two further influential publications attacked the quality and applicability of much 
contemporary educational research. Tooley and Darby (1998) rejected the validity of much education research and strongly reasserted the superiority of the school effectiveness agenda.

The DfEE/DfES's policy documentation and its appointed research centres made the transfer of evidence-based approaches from health a central objective of policy. It is evident from researching the documentary evidence that a 'medical model' of educational research was a clear priority in the UK. Three aspects of this cross-sectoral transfer are highlighted here.

First, Oakley (2000) suggested that education researchers adopt the experimental methods favoured by medical researchers and used by policy makers in health to establish evidence of effectiveness.

Why did experimental methods appear only to belong to natural science and to doctors? Why did they not seem to be owned equally by social science and other groups of professionals - for example, social workers, teachers and those involved in criminal justice and crime prevention? What was so special about those professions that made them immune to the need to show that their interventions in other peoples' lives worked and did more good than harm? (Oakley, 2000: 19)

Second, education research in the UK was criticized by Hargreaves (1996), Davies (1999) and later Blunkett (2000) for failing to be cumulative in knowledge creation, unlike the health sector where systematic reviews are more established as aids to policy makers and clinicians.

Such critics consistently looked at the American-influenced research base in health as a model. Again though, direct sectoral comparison was problematic. Healthcare enjoys an extensive, accessible evidence base, for example Oxford University's database of reviews in the Cochrane Collaboration. In education the most comprehensive quantitative databases are American. The American Educational Resources Information Centre (ERIC) sponsored by the US Department of Education, ${ }^{2}$ is a primary example, although PsycLIT, the American Psychological Society's international database, also covers education. Early syntheses of predominantly quantitative research studies in education were undertaken by the Cochrane Collaboration, which led to the initiation of an ambitious new cross-sectoral database, SPECTR (Social, Psychological, Educational and Criminological Controlled Trials Register). The Campbell Collaboration at the University of Pennsylvania is currently developing this international resource, which has reviewed over 10,000 randomized and quasi-randomized trials.

Davies (1999: 109) identified two strands in the movement for best evidence in education in the UK: utilizing 'existing evidence from world-wide (particularly American) research and literature on education and associated subjects'; and establishing 'sound evidence where existing evidence is lacking or of a questionable, uncertain or weak nature ... to plan, carry out and publish studies that meet the highest standards of scientific research and evaluation'. 
This required the development of a centralized British educational research database, based on the American health model. The DfEE/DfES EPPI-Centre was charged with developing protocols for conducting systematic reviews, providing an on-line bibliographic database, training and support for users seeking reviews, and the dissemination of findings of reviews. In addition, the Economic and Social Research Council (ESRC) funded a Co-ordinating Centre for Evidence-Based Policy and Practice at Queen Mary and Westfield College, directed by Professor Ken Young (Evans et al., 2000: 9). The National Foundation for Educational Research conducted a pilot review of educational research using the NHS Centre for Reviews and Dissemination guidelines. The National Educational Research Forum was established to provide a further steer on quality and aid to dissemination.

A third aspect of cross-sectoral transfer between health and education has been the commitment to engage in consultation with users to establish what they want from research. A number of consultation exercises have been conducted in the field of education to ascertain what the information needs of teachers, trainers and policy makers are. In the USA there have been studies by Everton et al. (2000) and McLaughlin (2000).

Subsequently, the TTA (Teacher Training Agency) funded small-scale, school-based teacher research projects followed by the establishment of school-based research consortia supported by HEIs (Higher Education Institutions). The rationale underpinning the research grants was the production of research that was useful, relevant and accessible. Building on earlier pilot work through the Excellence in Cities initiative, the DfEE/DfES similarly invested $£ 3 \mathrm{~m}$ through the Standards Fund for Best Practice Research Scholarships for teachers in September 2000; the project concluded in December 2004. The scope of these teacher-research projects was framed according to the strategic priorities indicated by the DfES. The National College for School Leadership continues to promote practitioner research through its ongoing Networked Learning Communities (NLC) programme established in September 2002.

Through these mechanisms, an 'Americanized', 'medicalized' model of evidence-based practice informed the basis of New Labour's approach to education. Defining the type of knowledge or research that should inform policy and practice has been instrumental for New Labour in controlling the educational state. This is most clearly demonstrated through the standards debate, throughout the sectors.

\section{THE 'AMERICANIZATION' OF BRITISH POST-COMPULSORY}

EDUCATION IN THE $1990 \mathrm{~s}$

In Dolowitz et al. (2000), I set down the processes involved in the Conservatives' use of American ideas and structures in the reform of higher education in the early 1990s. In sum, through the 1988 Education Reform Act, The Higher Education Reform Act of 1991 and the Further and Higher 
Education Reform Act of 1992, the British Government transferred very superficially the US notion of mass higher education, as was the model of 'marketization' in higher education. Market mechanisms such as student loans and managerial forms were borrowed and permeated the legislation. It was a flawed and very partial process. Some objectives were transferred from previous British policy and some US ideas, particularly on participation and inclusion, were 'ideologically filtered' to suit the Conservatives' ideological goals.

The government sought to transfer elements of the US system in order to achieve an easily controllable, expanded system at the least cost. With participation rates of around $15 \%$ of young people in Higher Education in late 1980s, the Conservatives were compelled to reform the University system in order to bridge the increasing gap with comparable countries. However, what was left behind was as important as what was transferred. Most of the 'equitable' aspects of higher education in the USA, where in many cities there have been successful attempts to target ethic minorities, women, and other under-represented groups, were ignored in the platform of legislation. This inevitably produced anomalies and problems leading to the Dearing Review's pessimistic evaluation of the system in 1997. The Review was in turn underpinned by information transferred from other countries - the USA again and also Australia - and represents in some ways a continuation of the importation of the US higher education system started in the 1980s. On an interorganizational level this process has been maintained by the continued importation of US higher educational forms and structures from 'semesterization' to modular degree structures and relationships with the private sector.

\section{USING TECHNOLOGY TO COMBAT SOCIAL EXCLUSION IN EDUCATION}

Hulme and Hulme (2000a, b) outline the case of multi-level transfer on the use of technology in a series of initiatives designed to combat 'social exclusion' in the late the 1990s. It is a case with interesting contrasts with other Americaninfluenced education policy. During the late 1990s, the British and American Governments formulated policies with the stated intention of enhancing the power of ICT (Information and Communication Technology) in the classroom while dealing with social exclusion. These aims, pursued through the National Grid for Learning (NGfL) and through New Labour's agenda for social inclusion via the establishment of Education Action Zones and Excellence in Cities (DfEE, 1997) were presented as distinctive projects in New Labour's 'third way' agenda in education. These initiatives were preceded by the American Democrats' 1996 National Plan for the Use of Technology in Schools, one of the US Government's few, truly national education policies of recent years. Clinton's plan formed a nearly verbatim blueprint for the NGfL. The then DfEE made frequent reference to lessons to be learned from the US experience and there was a marked similarity in the language and symbolism adopted in the promotion of the policy by Blair's and Clinton's governments. 
The US Education Department established an Office of Education Technology in 1996, which was emulated in the DfEE's allocation of the role for overseeing implementation of ICT policy in schools to the British Educational Communications and Technology Agency (BECTA). The government also sought intelligence from America to inform the presentation of its strategies for social inclusion in education. The Permanent Under Secretary for Education, Sir Michael Bichard, performed the role of transferring policy expert in making a series of visits to the USA, particularly New York, where he was briefed to examine the implementation strategies for combating social exclusion in inner city schools during 2000.

The case was significant due to the almost simultaneous nature of the transfer (and in the case of policy documentation its verisimilitude), ideological symmetry of the Anglo-American third way rhetoric and symbolism ('the learning society'), and the unique marriage of the policy goals of defeating social exclusion and the use of technology in education. This case also interests because it set in motion some innovative practice which was shared between public authorities in the UK and the USA. As Hulme and Hulme (2000a, b) and Hatcher (1996) demonstrate, the inner-city New York and Virginia case studies referenced in the DfEE's documentation stimulated some very productive contacts between city authorities in states and officers administering the UK initiatives in Education Action Zones in inner-city London and Birmingham. Ironically, some genuine international professional learning took place though these initiatives to enhance the use of technology in spite of the enhanced overall central control of education policy that these initiatives delivered.

\section{Applying the Policy Transfer Model}

The transfer of ideas and practices within the movement towards evidencebased practice in education provides an example of a multi-level policy transfer as outlined by Evans and Davies (1999). At the global level, Lester Thurow (1996) has referred graphically to the 'economic tectonic plates' remaking the economic 'surfaces' of social life. A number of academics have discussed the impact of globalization on policy making in education. Taylor et al. (1997: 57) have argued that: 'A global policy community may be emerging: globalization processes are affecting the cultural field within which education operates.'

Ball (1998) and Whitty and Edwards (1998) have taken this argument further, to assessing the rise of a generic global agenda in education. They find evidence of a generic platform of market reform in schools, reinforced by 'managerialism' and performance measurement, which provides a context for governments worldwide to define problems in education; this in turn determines the responses chosen. In part, this agenda reflects the international iteration of policy ideas; evidence-based practice is a significant part of 
this global agenda. Every western liberal democracy has a 'what works' policy. Education in Britain is sufficiently cross-sectoral - with well-developed networks, contacts with international organizations and featuring many opportunities for the cross fertilization of ideas - to be an ideal arena for the growth of an international market in policy ideas, and EBP is a prime example.

At the level of UK national policy networks, the government's attempt to transfer an Americanized medical approach to evidence-based practice in education has produced convergence in four areas. The EBP movements in education and health both place a strong emphasis on outcomes: the end result for the patient or gains in pupil attainment. Both stress the need for systematic reviews of research evidence to aid the cumulation of knowledge, i.e. the Cochrane Library and the DfEE/DfES EPPI-Centre. Both movements have made efforts to consult the target audience to identify the information needs of users, i.e. NHS consultation exercises (Jones et al., 1995) and surveys such as Everton et al. (2000). Both movements have adopted a predominantly (though more latterly not exclusively) positivist-informed, empiricist approach to research, e.g. the requirement for randomized controlled trials (RCTs) in medical research - 'Qualitative research findings are not considered evidence' (Cluett and Bluff, 2000); and the preference for 'experimentation' at the EPPI-Centre (Oakley, 2000). The uniformity in approach is further advanced through the development of cross-sectoral databases such as SPECTR in the USA and EPPI in the UK.

It is clear though, that transferring this approach has imported problems as well as benefits. There are tensions within the evidence-based movement and the transfer of the model to education has brought these to the fore. The problem of information overload has been documented in both sectors. Time and skill are needed to access, appraise and apply data to practice. It can be argued that teachers are not sufficiently trained or supported to use the wealth of performance data that is already available to them. Sebba (1999a, b) cites the example of the Essex Primary School Improvement (EPSI) programme, which revealed a strong 'tendency to accumulate unprocessed data' because teachers lacked the skills and confidence to analyse and interpret performance data. She calls for non-contact time for data-related activities to cope with the requirements of performance analyses.

Reliance on passive dissemination as a spur to action has proven inadequate in health and education circles. A common need is recognized to involve researchers in the active implementation of their findings at a grassroots level. In both sectors there continues to be debate over how to make research relevant to practitioners' needs.

Hargreaves (1996) claims that education researchers write for each other, unlike doctors who are users and researchers. He encourages teachers to adopt this model. However, doctors and teachers experience research differently. General practitioners' direct experience of research is likely to be as minor contributors to wider projects, i.e. as part of a wider group trialling 
interventions for the Medical Research Council or pharmaceutical company trials (Hannan et al., 1997). Teacher researchers are much more likely to be working in isolation, wholly responsible for research design, data collection and analysis.

There are of course different dimensions to professional power between the two sectors and this has consequences for the effectiveness of transfer. Professional bodies in the health arena have (traditionally at least) had an impact on policy. Medical expertise and professionalism is held in higher regard in Whitehall circles than teacher knowledge and expertise. Professional associations in education have had less success in shaping policy. The 'science of teaching' seeks not to value teachers' craft knowledge but to replace it. Improvement in clinical knowledge and practice is sought from within. Official school improvement efforts have been characterized as 'improvement from without'. Finally, research is connected with career progression and afforded a high status in the medical profession. Teachers routinely engaging in research (beyond award of a Master's degree) are likely to leave the profession.

At the inter-organizational level the relevance of the work of Ernst Haas $(1990,1992)$ becomes evident in the key role played by epistemic communities in the international movement of policy ideas. This case of EBP highlights the role of a trans-national epistemic community on evidence-based practice, which began in the field of American and Canadian medical research and grew to incorporate advocates of EBP in the British education research arena.

Certainly, the origin of the Government's approach to evidence-based practice can be traced to the Canadian medical community in the 1980s. This movement found its first application in Canadian approaches to teaching medical students in the 1980s, notably at the McMaster Medical School. This centre came to be seen as a model for solving clinical problems. Canadian research continues to be pioneered by the Health Information Research Unit at McMaster University, Ontario, ${ }^{3}$ which focuses on Evidence-Based Health Informatics to develop new resources to support evidence-based healthcare and the evaluation of various innovations in overcoming healthcare information problems.

The British evidence-based movement has been most strongly advocated by Professor David Sackett and colleagues at the NHS Research and Development Centre for Evidence-Based Medicine, Oxford. ${ }^{4}$ Several other UK centres for evidence-based medicine have been established. These include the NHS Centre for Reviews and Dissemination, ${ }^{5}$ established in York in 1994 to provide the NHS with information on treatment effectiveness and the organization and delivery of healthcare; and the UK Cochrane Centre, Oxford. ${ }^{6}$ The Canadian and American evidence-based movement had a significant influence on British medical education as seen in the development of designated centres such as the Unit for Evidence-Based Practice and Policy, Department of Primary Care and Population Sciences at the Royal Free and University 
College London Medical School; and the Centre for Evidence-Based Child Health at the Institute of Child Health and Great Ormond Street Hospital for Children NHS Trust, London. Healthcare professionals in nursing, mental health and dentistry have also embraced the evidence-based message.

The government's impetus to implement evidence-based healthcare in the UK grew from the early 1990s when the Department of Health estimated that only $15 \%$ of the interventions in use in the NHS were supported by 'unequivocal scientific evidence'. Moreover, effective innovations supported by evidence from RCTs were not being assimilated into practice sufficiently quickly with an obvious adverse impact on patient health (Evans et al., 2000: 6).

The role of the academics mentioned above provides us with interesting case study material on the multiple roles of certain actors in the transfer of policy ideas. The role of academics such as Hargreaves, Oakley, and Young clearly overarches that of epistemics, advocates and policy entrepreneurs. They are higher profile than most epistemics and permeate the whole of the policy process from trans-national to inter-organizational. The establishment of specialist research centres such as EPPI, NERF to serve the purposes of government in furthering the act of cross-sectoral and international transfer, and the dissemination of knowledge about transferred policy and practice raises interesting and as yet unresolved questions as to the role of structure and agent within the existing model of policy transfer. There is nothing unique about this case; the 'atmospheric influence' of key academic figures, particularly as expressed through think tanks, has been crucial in all of the examples. The role of Nexus and DEMOS for New Labour, and for the Conservatives' course the Institute of Economic Affairs and the Adam Smith Institute, among others, has been crucial. It is worth singling out, however, the power of key ideological texts in these cases. Thatcher's attempt to deliver a Hayekian market in education drew heavily on Chubb and Moe. Thomas and Pring (2004) identify two publications as having a particularly significant influence on the discourse underpinning UK policy making on EBP. First, Odden and Kelley's (1997) 'Paying Teachers for What They Know and Do' provided the basis for the Green Paper 'Teachers Meeting the Challenge of Change' (DfEE, 1998) and therefore the current introduction of performancerelated pay. Second, commissioned at a cost of $£ 4 \mathrm{~m}$, the Hay-McBer (2000) report is an attempt to identify 'the characteristics of a good teacher' in relation to the delivery of national standards. We argue that these two cultural importations are examples of partial transfer from which New Labour has borrowed selectively. Pring (2000) is critical of the centrist imposition of specific kinds of performance in the British interpretation of policy, arguing that in the US 'productivity targets' are developed by teachers and their representatives (especially the Board for Professional Teaching Practice), not by the state or federal government. 


\section{Conclusion}

The primary lesson to be learned from our examination of Anglo-American policy transfer is that in examining the origins of 'new' knowledge about policy - who supplies such knowledge and the political and practical purposes to which this knowledge is put - we can understand more about the nature of policy development and the chances of its success at any level.

The act of international policy learning through the transfer of ideas, institutions and practices via international networks and communities represents one of the primary instruments in the development of global social policy, and nowhere is this more evident than in the American influence on British education policy. The drive towards evidence-based practice is a part of a global shift towards forms of new public management informed by a perception of radical global economic change and the need for modernization to raise standards and maintain competitiveness in public services.

The literature that we have to date suggests that British governments have looked to America for very general political symbols or a quick fix to an immediate problem. Consequently, partially transferred ideas have produced contradictory or flawed policy. The case of evidence-based practice in education sheds light on the processes of the increasing internationalization of education policy through the iteration of generic agendas, but also provides us with an example of British Government's proclivity to learn very selectively and expediently from other contexts in order to realize their political goals. A focus on the origins of these ideas, through the influence of American 'epistemics' and health structures and direct transfer of practice from the health sector in the UK, helps us to expose the tensions within New Labour's ideological discourses and to criticize more effectively the true intent and efficacy of their education policy.

It is evident from the transfer literature that policy informed by US practice often fails due to the political, social, cultural and administrative specificity of its origins. Many aspects of policy and practice outlined in the examples presented here are not 'transferable'. There are a number of structural and cultural constraints on the flow of ideas and instruments across the Atlantic. In many respects we are not comparing 'like with like'. Ironically, the 'differentness' of the US Federal system is one of the main attractions of the USA to British policy makers. The US system faces similar problems, often with different manifestations - retention rates, social exclusion, etc., but there are many different test cases in terms of state governments attempting to find responses to them. Despite the oft noted complexity of British education policy, the logistics of central government control from Washington and therefore, the politics of central-local relations are very different in the USA. The implementation of Washington's national agendas such as the example of the National Plan for Technology is negotiated through a series of local agendas. 
The unreconstructed transfer of structures and mechanisms from individual states effectively bypasses this negotiation and has contributed to Britain's democratic deficit in education policy making. Furthermore, as the EBP example has demonstrated, the academic culture of US education from primary to higher is very different. In particular, the level of curricular autonomy enjoyed by teachers in most states does not make for the effective transfer of structures. It is ironic, though, that those aspects of the US system that gave teachers the autonomy to innovate have been undermined by a rare case of transfer from the UK (Hulme and Hulme, 2000a, b). The English and Welsh national curriculum inspired the Standards of Learning Tests (SOLs), introduced throughout the USA in 1999-2000. The tests have changed the way the curriculum is delivered. Seventy percent of students in each school must pass the exams given in English, Maths, History and Science. Since 2004, schools have lost state accreditation if too many students fail the examinations.

The examples offered here have demonstrated that most of the attempts to transfer education policy ideas from the US have failed either in the sense that they have not delivered the stated goals of government or in terms of having unintended outcomes. The major lesson from these various instances of failure is that education policy informed by practice elsewhere is likely to fail unless sufficient notice is taken of the context of practice both in the place where the policy originates and in the transferring country. The most effective transferred knowledge is that which comes from the 'bottom-up', from organizations seeking good practice from each other, academics or teachers sharing good practice across communities of learning, academics seeking to diffuse their research and perhaps, organizations seeking ideas as 'policy entrepreneurs'. In governing education, New Labour should seek to learn the lesson offered by the more positive examples that the transfer literature has to offer from the inter-organizational level: that the key to success depends on the political will of those seeking change and the extent to which all actors are 'included' in the processes and outcomes of change. Rather, the majority of case study material on Anglo-American policy transfer reminds us that when British governments have borrowed policy instruments (rather than broader discourses, symbols and rhetoric) from the USA, they have sought means of controlling particular policy domains. In this sense, EBP follows a familiar pattern since it is difficult to conclude that New Labour's policy making has genuinely engaged with the body of knowledge offered by the broader research communities in education or health.

NOTES

1. The work presented here on evidence-based practice in education is based on Hulme and Hulme (2004).

2. ERIC indexes over 775 periodicals and currently contains more than 700,000 records. It is the largest education database in the world, covering research 
documents, journal articles, technical reports, programme descriptions and evaluations and curricular materials. ERIC contains data from 1966 onwards and is updated monthly.

3. http://hiru.mcmaster.ca/default.htm

4. http://cebm.jr2.ox.ac.uk

5. http://www.york.ac.uk/inst/crd/welcome.htm

6. The Cochrane collaboration is an international organization that aims to make up-to-date, accurate information about the effects of healthcare readily available worldwide. It produces the Cochrane Database of Systematic Reviews. There are a number of Cochrane Centres around the world.

\section{REFERENCES}

Ball, S. (1990) Politics and Policy Making in Education. London: Routledge.

Ball, S. (1998) 'Big Policies/Small World: An Introduction to International Perspectives in Education Policy', Comparative Education 34(2): 119-30.

Blunkett, D. (2000) 'Influence or Irrelevance: Can Social Science Improve Government?', Research Intelligence 71: 12-21.

Cluett, E.R. and Bluff, R. (2000) Principles and Practice of Research in Midwifery. Edinburgh: Ballière Tindall.

Daguerre, A. and Taylor-Gooby, P. (2004) 'Neglecting Europe: Explaining the Predominance of American Ideas in New Labour's Welfare Policies Since 1997', Fournal of European Social Policy 14(1): 25-39.

Davies, H.T.O., Nutley, S.M. and Smith, P.C. (eds) (2000) What Works? Evidence-Based Policy and Practice in Public Services. Bristol: Polity Press.

Davies, P. (1999) 'What is Evidence-Based Education?', British Fournal of Educational Studies 47(2): 108-21.

Deacon, A. (2000) 'Learning from the US?: The Influence of American Ideas Upon "New Labour" Thinking on Welfare Reform', Policy and Politics 28(1): 5-18.

DfEE (1997) 'Excellence in Schools', White Paper. London: DfEE HMSO.

DfEE (1998) Teachers Meeting the Challenge of Change. London: DfEE HMSO.

Dolowitz, D. and Marsh, D. (1996) 'Who Learns What From Whom? A Review of the Policy Transfer Literature', Political Studies 44(2): 343-57.

Dolowitz, D. with Hulme, R., Nellis, M. and O'Neal, F. (2000) Policy Transfer and British Social Policy. Buckingham: Open University Press.

Evans, J., Sharp, C. and Benefield, P. (2000) 'Systematic Reviews of Educational Research: Does the Medical Model Fit? National Foundation for Educational Research', paper presented at the British Educational Research Association Conference, Cardiff University, 7-10 September.

Evans, M. and Davies, J. (1999) 'Understanding Policy Transfer: A Multi-Level, Multi-Disciplinary Perspective', Public Administration 77(2): 361-85.

Everton, T., Galton, M. and Pell, T. (2000) 'Teachers' Perspectives on Educational Research: Knowledge and Context', fournal of Education for Teaching 26(2): 167-82.

Fischer, F. and Forrester, J. (1993) The Argumentative Turn in Policy Analysis and Planning. Durham, NC: Duke University Press.

Haas, E. (1990) When Knowledge is Power: Three Models of Change in International Organizations. Berkeley: University of California Press.

Haas, E. (1992) 'Introduction: Epistemic Communities and International Policy Co-ordination', International Organisation 46(1): 1-35. 
Hannan, A., Enright, H. and Ballard, P. (1997) 'Using Research: The Results of a Pilot Study Comparing Teachers, General Practitioners and Surgeons', accessed January 2006, http://www.leeds.ac.uk/educol/documents/000000851.htm

Hargreaves, D. (1996) 'Teaching as a Research-Based Profession: Possibilities and Prospects', British Educational Research fournal 23(2): 141-61.

Hatcher, R. (1996) 'The Limitations of the New Social Democratic Agendas', in R. Hatcher and K. Jones (eds) Education after the Conservatives. Stoke on Trent: Trentham Books.

Hay/McBer (2000) 'Research into Teacher Effectiveness', accessed 21 March 2006, http://www.teachernet.gov.uk/_doc/1487/haymcber.doc

Hulme, R. and Hulme, M. (2000a) 'Using Technology to Combat Social Exclusion in Education: The Limits of Lesson-Drawing From the USA', Education and Social Fustice 3(1): 34-44.

Hulme, R. and Hulme, M. (2000b) 'How Good Practice in Virginia Can Influence Change in England: Trans-Atlantic Lesson Drawing in the Use of Technology in Teaching', Contemporary Issues in Technology and Teacher Education CITE Summer 2000, accessed 27 January 2006, http://www.citejournal.org/vol1/iss2/currentpractice/ article1.htm

Hulme, R. and Hulme, M. (2004) 'Policy Transfer and Evidence Based Practice in Education', paper presented at British Education Research Association, Social Justice SIG Seminar, University of Northampton, 4 May.

Jones, K. (ed.) (1996) Education after the Conservatives. Stoke on Trent: Trentham Books. Jones, R., Lamont, T. and Haines, A. (1995) 'Setting Priorities for Research and Development in the NHS: A Case Study on the Interface Between Primary and Secondary Care', British Medical Fournal 311: 1076-80, accessed 27 January 2006, http://bmj.bnjjournals.com/cgi/content/full/311/7012/1076

King, D. (1999) In the Name of Liberalism: Illiberal Social Policy in the United States and Britain. Oxford: Oxford University Press.

McKibbon, K.A. (1998) 'Evidence Based Practice', Bulletin of the Medical Library Association 86(3): 396-401

McLaughlin, C. (2000) 'Parallel Processes in Learning to Learn: A School/University Partnership Focussed on Developing the Social Aspects of Pedagogy', in M. Griffiths and G. Impey (eds) Working Partnerships: Better Research and Learning (pp. 77-91). Nottingham: Nottingham Trent University.

Marsh, D. and Rhodes, R.A.W. (1993) Policy Networks in British Government. Oxford: Clarendon.

Oakley, A. (2000) Experiments in Knowing: Gender and Method in the Social Sciences. Cambridge: Polity Press.

Odden, A. and Kelley, C. (1997) Paying Teachers for What They Know and Do. Thousand Oaks, CA: Corwin Press.

Olssen, M., Codd, J. and O’Neill, A. (2004) Education Policy, Globalisation, Citizenship \& Democracy. London: Sage.

Pring, R. (2000) Philosophy of Educational Research. London: Continuum.

Rose, R. (1991) 'What is Lesson Drawing?', Fournal of Public Policy 11(1): 1-22.

Sabatier, P. and Jenkins-Smith, H. (eds) (1993) Policy Change and Learning: An Advocacy Coalitions Approach. Boulder, CO: Westview Press.

Sebba, J. (1999a) 'Examples of Schools' Approaches to Collecting Data', paper presented at the British Educational Research Association Annual Conference, University of York, 11-14 September. 
Sebba, J. (1999b) 'Developing Evidence-Informed Policy and Practice in Education', paper presented at the British Educational Research Association Conference, University of Sussex, Brighton, 2-5 September.

Stone, D. (ed.) (2000) Banking on Knowledge: The Genesis of the Global Development Network. London: Routledge.

Stone, D. (2001) 'Think Tanks, Global Lesson Drawing and Networking Social Policy Ideas', Global Social Policy 1(3): 338-60.

Taylor, S., Rizvi, F., Lingard, B. and Henry, M. (1997) Education Policy and the Politics of Change. London: Routledge.

Thomas, G. and Pring, R. (eds) (2004) Evidence-Based Practice in Education. Maidenhead: Open University Press.

Thurow, L. (1996) The Future of Capitalism. St Leonards: Allen and Unwin.

Tooley, J. with Darby, D. (1998) Educational Research: A Critique. London: Ofsted.

Whitty, G. and Edwards, T. (1998) 'School Choice Policies in England and the United

States: An Exploration of their Origin and Significance', Comparative Education 34(2): 211-27.

RÉS UMÉ

\section{Le Rôle de la Transfère Politique dans l'évaluation de l'impact des Idées Américaines sur la Politique Sociale Britannique}

Cet article examine la contribution des ouvres actuelles concernant le transfert politique à nos connaissances à propos du changement politique sur la scène internationale. Il explore l'impact des idées et des pratiques Américains sur des aspects de la politique sociale au Royaume-Uni. L'article est centré sur l'examen du rôle des 'communautés épistémiques' et l'apprentissage politique dans le développement des agendas génériques internationaux, tel que le modèle médical 'américanisé' des 'pratiques basées sur l'évidence' (model of evidence-based practice) adopté par le gouvernement New Labour par rapport à la santé et l'éducation. Finalement, l'article propose que l'analyse de la politique internationale sociale doit tenir compte du mouvement des idées et des pratiques à trois niveaux: globalement/internationalement, nationalement, et à l'intérieur des organisations.

RES UMEN

\section{El Papel de la Transferencia Política en la Valoración del Impacto de las Ideas Americanas Sobre la Política Social Británica}

Este artículo examina la contribución de los trabajos existentes en transferencia política a nuestro conocimiento sobre el cambio político a nivel internacional. El texto explora el impacto de las ideas y prácticas americanas sobre determinados aspectos de la política social del Reino Unido. Concretamente, el artículo se centra en el papel de las 'comunidades epistémicas' y del aprendizaje político en el desarrollo de agendas genéricas internacionales tales como el modelo 'médico americanizado' de 'práctica 
basada en evidencia' ('evidence-based practice') adoptado por el nuevo gobierno laborista en sanidad y educación. El artículo argumenta que el análisis de la política social internacional debería tener en cuenta el movimiento de ideas y prácticas a tres niveles: global/internacional, nacional e inter-organizacional.

\section{BIOGRAPHICAL NOTE}

Rob hulme is a Professor of Education Policy with the School of Education at the University of Chester. He has published managed research projects about policy transfer and the international movement of ideas and practice in education and social policy, both in theory and practice, for a number of years. His focus has encompassed Anglo-American policy transfer and international professional learning in the development of social and education policy capacity in Russia and the NIS. He has recently given papers on these themes at the University of California, Berkeley and Cambridge University. Please address correspondence to: Rob Hulme, University of Chester, School of Education, University of Chester, Parkgate Road, Chester CH1 4BJ. [email: r.hulme@chester.ac.uk] 